\title{
MINERAL RESOURCE POTENTIAL AND GEOLOGY OF THE HUSTON PARK ROADLESS AREA, CARBON COUNTY, WYOMING
}

\author{
By \\ R. S. Houston and T. G. Schmidt, U.S. Geological Survey \\ and \\ M. E. Lane, U.S. Bureau of Mines
}

Studies Related to Wilderness

Under the provisions of the Wilderness Act (Public Law 88-577, September 3, 1964) and related acts, the U.S. Geological Survey and the U.S. Bureau of Mines have been conducting mineral surveys of wilderness and primitive areas. Areas officially designated as "wilderness," "wild," or "canoe" when the act was passed were incorporated into the National Wilderness Preservation System, and some of them are presently being studied. The act provided that areas under consideration for wilderness designation should be studied for suitability for incorporation into the Wilderness System. The mineral surveys constitute one aspect of the suitability studies. The act directs that the results of such surveys are to be made available to the public and be submitted to the President and the Congress. This report discusses the results of a mineral survey of the Huston Park Roadless Area, Medicine Bow National Forest, Carbon County, Wyoming. Part of the Huston Park Roadless Area (C2087) was classified as a further planning area during the Second Roadless Area Review and Evaluation (RARE II) by the U.S. Forest Service, January 1979.

\section{MINERAL RESOURCE POTENTIAL SUMMARY STATEMENT}

The Huston Park Roadless Area is underlain, in part, by Proterozoic volcanic rocks that are believed to have been deposited in an island arc setting. Volcanic rocks of this type may contain stratiform sulfide deposits of significance, and several prospects that have geologic settings of stratiform sulfide deposits were identified during this study. All prospects were outside the Huston Park Roadless Area, however, and neither geologic nor geochemical results indicated mineralization in the volcanic rocks of the roadless area. Because of the favorable geologic terrane, we conclude that the Huston Park Roadless Area has a moderate potential for copper resources in the volcanic rocks.

The bulk of the Huston Park Roadless Area is underlain by Proterozoic granite that intrudes the volcanic succession and older granodiorite and gabbro. This granite was analyzed for tin and tungsten because tin- and tungsten-bearing granites are found in geologic settings like that of the roadless area and vicinity. Granites of the southern Sierra Madre do have some anomalous tin values, but of 11 samples from the Huston Park Roadless Area only one was found to have anomalous tin.

\section{INTRODUCTION}

The Huston Park Roadless Area is in the southwestern Sierra Madre, Medicine Bow National Forest, Carbon County, Wyo. (fig. 1). The roadless area and adjacent areas included in this investigation make a total of about $50 \mathrm{mi}^{2}$. The roadless area includes parts of the drainage areas of the Roaring Fork Branch of the Little Snake River and the West Branch of the North Fork of the Little Snake River. Elevations in the roarlless area range from 8,000 to $9,200 \mathrm{ft}$; the lower elevations are characterized by open parks and meadows and the higher elevations are well timbered. The area is accessible by dirt roads that connect with Wyoming gravel road 70 between Encampment and Baggs; accessibility is limited to summer and early fall and to dry periods because these dirt roads are extremely hazardous after significant precipitation.
During 1981 and 1982, the U.S. Geological Survey and U.S. Bureau of Mines conducted field investigations to evaluate the mineral resource potential of the Huston Park Roadless Area. Field studies included geologic mapping and investigations, geochemical sampling of rocks and stream sediments, examination of mines and prospects, and a search for mineralized areas.

\section{GEOLOGY}

The general area is underlain by Proterozoic metavolcanic rocks, ranging in composition from basalt to rhyolite, which are intruded by Proterozoic granodiorite, gabbro, and granite. West-dipping Paleozoic and Mesozoic sedimentary rocks crop out at the western edge of the general area, and gently dipping sedimentary beds of Miocene age lie unconformably on older rocks and cover much of the 

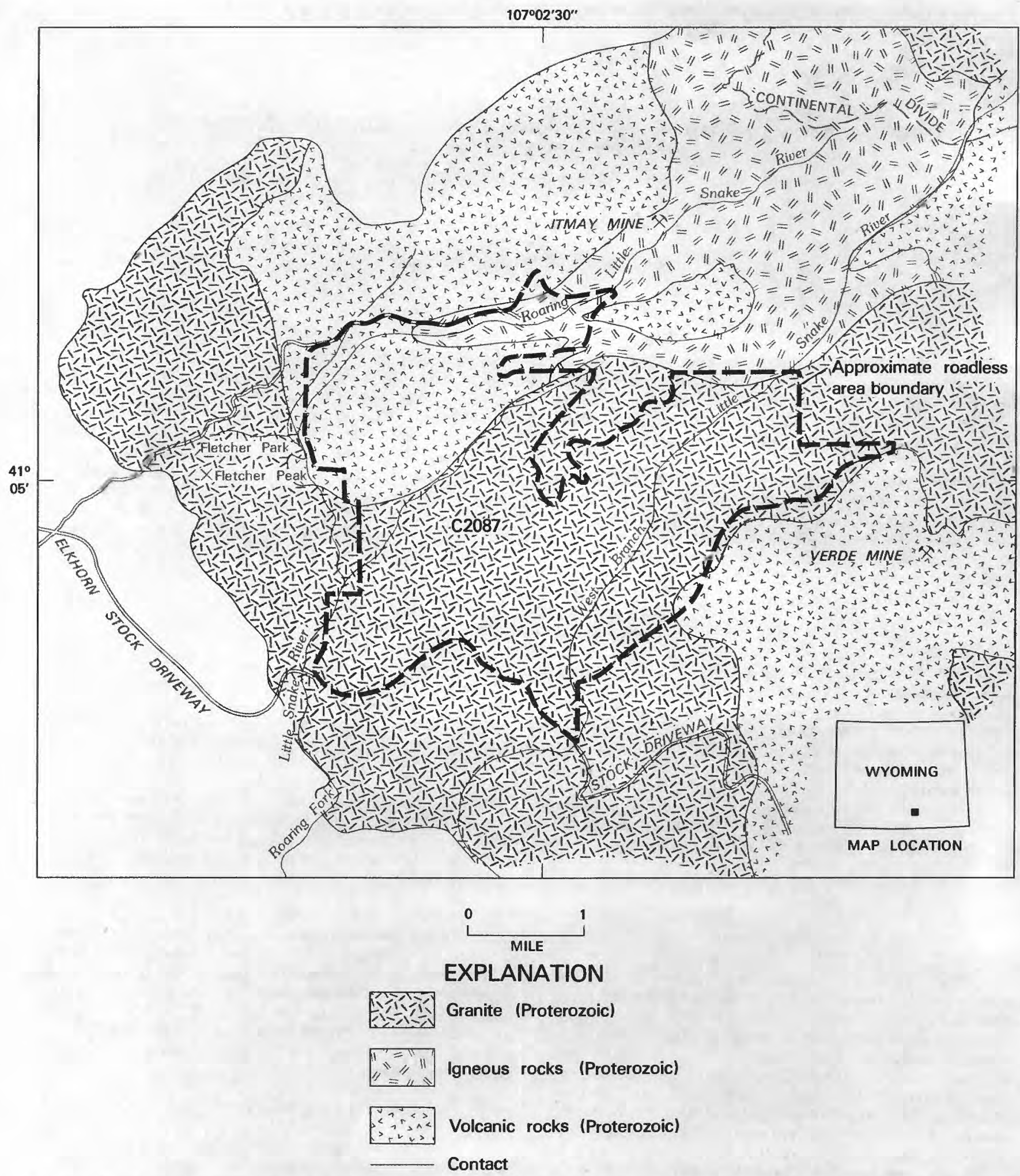

Figure 1.-Map showing location and simplified geology of the Huston Park Roadless Area (C2087) and adjacent areas, Wyoming. 
western one-fourth of the general area. The Huston Park Roadless Area is underlain primarily by granite, but metavolcanic rocks are present in the northern part of the roadless area (fig. 1).

The Huston Park Roadless Area lies $3 \mathrm{mi}$ south of the Cheyenne Belt (Houston and others, 1979), an eastto northeast-striking zone of highly deformed and sheared rocks. The Cheyenne Belt marks the boundary between the Archean Wyoming Province on the north and Proterozoic X (Early Proterozoic) metasedimentary, metavolcanic, and intrusive rocks in southeastern Wyoming and northern Colorado on the south.

The Cheyenne Belt has been interpreted (Hills and Houston, 1979) to be a Proterozoic suture where island arcs and (or) microcontinents, located in what is now Colorado, were attached to the rifted margin of a continental mass consisting chiefly of Archean rocks. This interpretation assumes that highly deformed and metamorphosed mafic and felsic gneisses and schists of southeastern Wyoming and northern Colorado were originally volcanic rocks and graywacke (Houston and others, 1968). Geologic mapping completed as part of this study and other geologic mapping projects conducted in the late 1970's and 1980's in the central and western Sierra Madre (Divis, 1976; Swift, 1982; Mueller, 1982) demonstrated that the metamorphic rocks of the central and western Sierra Madre are indeed volcanic and have many of the characteristics of an island arc succession. The verification of a volcanic origin for these rocks is significant regarding mineral potential inasmuch as island arc volcanic successions often are hosts of stratiform mineral deposits.

A mixed succession of metavolcanic rocks and clastic metasedimentary rocks crops out along the southeastern boundary. of the roadless area. This metavolcanic succession has not been mapped as part of this study, but some information on these rocks is available from earlier work (Divis, 1976; Swift, 1982). These metavolcanic rocks originally consisted of a sucession of tuffs and flows of rhyolite, rhyodacite, dacite, and basalt, interlayered with graywacke, arkose, and quartzite. The succession is believed to be part of the metavolcanic sequence described north of the area, but the rocks are finer grained in the south and are probably a more distal facies. Pillow basalts have been recognized in these rocks by Swift (1982). A bed of chemical sediment containing chalcopyrite and pyrite is present in this succession about $1 \mathrm{mi}$ eastsoutheast of the area in $\mathrm{N} 1 / 2$ sec. $32, \mathrm{~T} .13 \mathrm{~N}$., R. $86 \mathrm{~W}$.

The roadless area is underlain mostly by granite, but other intrusive rocks, including granodiorite and gabbro, are present (fig. 1). Metavolcanic rocks occur as isolated blocks and masses of various dimensions within the intrusive bodies. The largest mass of metavolcanic rocks underlies an area of about $11 / 2$ $\mathrm{mi}^{2}$ in secs. 21 and 28, T. 13 N., R. $86 \mathrm{~W}$. The only bed of chemical sediment recognized in this exposure is a siliceous iron-formation in rhyolite in the NE1/4 sec. 28, T. $13 \mathrm{~N}$., R. $86 \mathrm{~W}$. No sulfide minerals were recognized at this locality.

The metavolcanic rocks of this general area have better preserved textures and structures than any in southeastern Wyoming or northern Colorado despite the fact that they are amphibolite facies. Topping criteria in the metasedimentary and metavolcanic rocks are not well preserved everywhere in the area so it is not possible to establish a complete stratigraphic section, but a partial stratigraphic section has been measured about $1 \mathrm{mi}$ north of the roadless area. This section (table 1) includes $16,465 \mathrm{ft}$ of metavolcanic rocks and metagraywacke and contains two sequences consisting originally of rhyolite breccia overlain by chemical sediments (chert, iron formation, carbonate). It is in this type of geologic setting that volcanogenic stratiform sulfide deposits occur (Sangster, 1972; Franklin and others, 1981). Iron and copper sulfides have been identified at the contact with rhyolite breccia in an old mine located in the SE1/4 sec. $11, T .13$ N., R. 86 W., approximately $1 \mathrm{mi}$ north of the roadless area. This occurrence is in the upper layer of chemical sediments (table 1). No sulfides have been identified in the lower layer.

Granodiorite, which is part of a larger intrusive body of the central Sierra Madre (Lackey, 1965; Divis, 1976), crops out in the northeastern part of the mapped area and invades the metavolcanic succession in the northern and eastern part of the roadless area. The granodiorite has a well-developed foliation and is characterized by numerous inclusions of amphibolite which were probably mafic volcanic rocks. Zircon from the granodiorite has been dated as $1,780 \pm 5 \mathrm{~m} . \mathrm{y}$. by the uranium-lead method (Premo and Van Schmus, 1982), and because the granodiorite cuts the metavolcanic succession it establishes a minimum age for these rocks.

Two large masses and several smaller bodies of gabbro crop out in the southwestern part of the roadless and adjacent areas. This massive, mediumgrained gabbro is similar to the gabbro of Elkhorn Mountain, which crops out in the northwestern Park Range of Colorado and southwestern Sierra Madre Range (Snyder, 1980). Zircon from the gabbro of Elkhorn Mountain has been dated by the U-Pb method as 1,781 m.y. (C. E. Hedge, quoted in Snyder, 1980). Thus, if the two gabbros are correlative, the gabbro of the study area is about the same age as the granodiorite.

The most abundant rock type in the Huston Park Roadless Area is a pink, faintly foliated granite that underlies all of the eastern, central, and southern parts of the roadless area and borders the roadless area on the west. The granite intrudes all rocks and is the youngest rock of the area. The granite of this area has not been dated but similar granite and quartz monzonite from elsewhere in the Sierra Madre and northern Park Range have been dated as about 1,700 m.y. (Hills and Houston, 1979; Snyder, 1980; Premo and Van Schmus, 1982).

West-dipping Paleozoic and Mesozoic sedimentary rocks crop out southwest of the area and lie unconformably on the Proterozoic rocks. Gently dipping, largely unconsolidated, continental sedimentary rocks of Miocene age (Browns Park and North Park Formations) lie unconformably on older rocks and extend into the western part of the study area. Glacial deposits of Pleistocene age are present in valleys and underlie large areas in the east-central part of the mapped area.

\section{GEOCHEMISTRY}

A total of 13 stream-sediment and 101 rock samples from the roadless area were collected by $R$. S. 
Table 1.--Stratigraphy of a part of the metavolcanic rocks of the Huston Park Roadless Area [Leaders (--) indicate no data]

\begin{tabular}{|c|c|c|}
\hline Age & Rock description & Thickness (ft) \\
\hline $\begin{array}{l}\text { Proterozoic } x \\
\left(1,800 \mathrm{~m} \cdot \mathrm{y}_{\cdot}\right)\end{array}$ & Granodiorite (intrusive) & -- \\
\hline \multirow{6}{*}{$\begin{array}{l}\text { Proterozoic } x \\
\text { (older than about } \\
1,800 \mathrm{~m} \cdot \mathrm{y}^{-} \text {). }\end{array}$} & Graywacke- & 500 \\
\hline & $\begin{array}{l}\text { Iron-formation (magnetite) } \\
\text { Local sulfide on dumps of prospect pits and mines } \\
\text { Rhyolite breccial }\end{array}$ & 100 \\
\hline & Rhyolite tuff & 300 \\
\hline & Rhyolite breccia- & 100 \\
\hline & Rhyolite crystal tuff & 500 \\
\hline & $\begin{array}{l}\text { Rhyolite breccia; locally layered possible } \\
\text { crossbedding. }\end{array}$ & 970 \\
\hline \multirow{15}{*}{$\begin{array}{l}\text { Proterozoic } x \\
\text { (older than about } \\
1,800 \mathrm{~m} \cdot \mathrm{y}_{\cdot} \text { ). }\end{array}$} & $\begin{array}{l}\text { Graywacke; layered, some graded beds, locally } \\
\text { concretionary. }\end{array}$ & Over 2,800 \\
\hline & Rhyolite breccia and arkose & 400 \\
\hline & $\begin{array}{l}\text { Dacitic agglomerate, flows, and tuff, some tuff } \\
\text { beds are graded; large clasts rounded. }\end{array}$ & 1,200 (approx.) \\
\hline & $\begin{array}{l}\text { Basaltic agglomerate, flows, and tuff, some tuff } \\
\text { beds are graded; large clasts rounded. }\end{array}$ & 1,700 (approx.) \\
\hline & Iron-formation (magnetite) & Variable \\
\hline & Calc-silicate, carbonate, chert- & Variable 200 \\
\hline & Rhyolite breccia- & 750 \\
\hline & Rhyolite crystal tuff & 350 \\
\hline & Rhyolite tuff & 1,075 \\
\hline & Interlayered rhyolite and andesite agglomerate-_...- & 720 \\
\hline & $\begin{array}{l}\text { Interlayered basaltic and andesitic tuff and } \\
\text { agglomerate; intruded by rhyolite dikes. }\end{array}$ & 1,440 \\
\hline & Andesite tuff, minor agglomerate- & 1,000 \\
\hline & Dacitic agglomerate and lapilli tuff- & 1,100 \\
\hline & $\begin{array}{l}\text { Interlayered andesitic agglomerate, tuff, and } \\
\text { graywacke. }\end{array}$ & 560 \\
\hline & Rhyolite tuff & 700 \\
\hline
\end{tabular}


Houston and T. G. Schmidt. The stream-sediment samples, averaging about $11 / 2 \mathrm{lb}$ each, were collected along flowing streams.

All samples were analyzed by D. E. Siems and Betty Adrian of the U.S. Geological Survey, using a six-step semiquantitative spectrographic method for 30 elements ( $\mathrm{Au}, \mathrm{Ag}, \mathrm{As}, \mathrm{B}, \mathrm{Ba}, \mathrm{Be}, \mathrm{Bi}, \mathrm{Ca}, \mathrm{Cd}, \mathrm{Co}, \mathrm{Cr}$, $\mathrm{Cu}, \mathrm{Fe}, \mathrm{La}, \mathrm{Mg}, \mathrm{Mn}, \mathrm{Mo}, \mathrm{Nb}, \mathrm{Ni}, \mathrm{Pb}, \mathrm{Sb}, \mathrm{Sc}, \mathrm{Sn}, \mathrm{Sr}, \mathrm{Ti}$, $\mathrm{V}, \mathrm{W}, \mathrm{Y}, \mathrm{Zn}$, and $\mathrm{Zr}$ ). The spectrographic data were reported to the nearest number in the series $1,0.7$, $0.5,0.3,0.2,0.15,0.1$, and so forth, which represent approximate midpoints of grouped data on a geometric scale. Selected samples from this set were also analyzed by J. Sharkey of the U.S. Geological Survey for $\mathrm{Au}, \mathrm{Zn}, \mathrm{Cd}, \mathrm{Bi}, \mathrm{Sb}, \mathrm{As}$, and $\mathrm{Sn}$ using atomicabsorption technique and for tungsten using a quantitative spectrographic technique.

Of the 13 stream-sediment sainples collected, none had anomalous amounts of the elements analyzed. The stream-sediment samples were relatively uniform in composition and are believed to reflect the composition of glacial deposits rather than the composition of bedrock. Of the 101 rock samples analyzed, 17 contained anomalous amounts of the elements analyzed (table 2). The anomaly minima (table 2) were selected by comparison of values with averages for specific rock types given in the literature (Wedepohl, 1969-1978).

Samples $80-28$ and TG30-81 are of massive sulfides from an old mine dump located on a contact between rhyolite breccia and chemical sediments. This contact is a prime candidate for a stratiform deposit. Sample $80-29$ is from the Itmay mine dump. In all of the samples having anomalous values the principal metals are copper and iron although modest values in silver, molybdenum, cobalt, tin, tungsten, and nickel are present. Only one of these samples (TG3081) was analyzed by the atomic-absorption method and it contained 0.20 parts per million (ppm) gold. Sample 81-32 is from a set of oxidized sulfide veinlets (now mostly malachite) in rhyolite; in addition to copper this sample contains anomalous amounts of lead and silver.

Four samples $(80-27,80-36,81-31$, TG66-81) were collected from magnetite iron-formation and, as expected, these samples contained 15-20 percent iron. Two of these samples (81-31 and TG66-81) contained copper, cobalt, and tungsten. The cobalt content of $81-31$ is an interesting anomalous value for iron-formation, but the iron-rich bed contains sulfide minerals and may be transitional between iron formation and stratiform sulfide. The magnetite crops out in a prospect pit and cannot be traced on the surface. Nonetheless it might be worthwhile to examine all iron-formations in the general area to see if metals such as cobalt and gold are present in beds having greater continuity. Sample TG73-81 is from an outcrop of massive specular hematite, about $20 \mathrm{ft}$ long and $2 \mathrm{ft}$ wide, that may be the oxidized surface expression of iron-formation or some type of gossan; this hematite-rich layer contains surprisingly high tungsten values (45 ppm) along with $0.10 \mathrm{ppm}$ gold and 1,500 ppm copper.

Sample $80-20$ is from a siliceous carbonate that overlies rhyolite breccia. The carbonate is a potential target area for stratiform deposits. This sample contains 1,000 ppm zinc.
All samples that contain anomalous metal values were collected north of the Huston Park Roadless Area, except samples $80-36$ and TG66-81 from the iron-formation (NE1/4 sec. 28, T. 13 W., R. 86 W.) within the roadless area.

\section{MINING DISTRICTS AND MINERALIZED AREAS}

Review of courthouse and U.S. Bureau of Land Management records shows that Continental Oil Company (Conoco) has located claims north and east of the roadless area; a few of the claims extend into the northern portion. Eighteen claims were located in the Verde mine area east of the roadless area and the rest were located north of the roadless area. Only one prospect pit was found in the Huston Park Roadless Area. This prospect pit is in altered (epidotized and silicified) rhyolite in the center of sec. $21, T .13$ N., R. 86 W., but no sulfide minerals were detected. Siliceous iron-formation found in the NE1/4 sec. 28 , T. 13 N., R. $86 \mathrm{~W}$. is believed to be a chemical sediment that could overlie sulfide deposits, but no mineralized areas were recognized in surface outcrops.

Old prospects and mines approximately $1 \mathrm{mi}$ north of the Huston Park Roadless Area (Itmay mineStandard mine area; fig. 1) mark excellent exploration targets for stratiform sulfide deposits. These mines and prospects fit most of the criteria for stratiform sulfide occurrences as cited by Sangster (1972): (1) occurrence in calc-alkaline, submarine, volcanic rocks; (2) spatial correlation with felsic, explosive phase of volcanism; (3) massive and disseminated ore; and (4) overlain by siliceous iron-formation.

The significance of mineral occurrences north of the Huston Park Roadless Area was recognized by geologists of the minerals division of Conoco and both the lower and upper layer of chemical sediments were drilled during 1981. Conoco drilled three shallow holes and three deeper holes within $0.5 \mathrm{mi}$ of the north boundary. Results of the drilling have indicated favorable geologic environments for massive sulfides, and some sulfide minerals were encountered. Whether or not the mineralized area extends into the Huston Park Roadless Area is not known at this time.

A mineralized chemical sediment layer located about $1 \mathrm{mi}$ east-southeast of the roadless area has been referred to as the Verde or Hinton mine (Spencer, 1904; fig. 1) and was in operation from about 1900 to 1906. The mineralized zone has some of the characteristics of a stratiform sulfide deposit and it may be a fine-grained distal facies of metavolcanic rocks north of the Huston Park Roadless Area. Minerals including chalcopyrite, pyrite, and magnetite were noted in mine dump samples. The main shaft is on a contact between a felsic breccia on the south and cherty iron-formation on the north.

\section{ASSESSMENT OF MINERAL RESOURCE POTENTIAL}

The metavolcanic rocks in the Huston Park Roadless Area and adjacent areas are interpreted to have originated as island arc volcanic successions and are therefore favorable sites for the presence of stratiform sulfide deposits. Specific geologic environments favorable for stratiform sulfide (Sangster, 1972) exist at two localities north of the roadless area, and sulfide mineralization is present in 


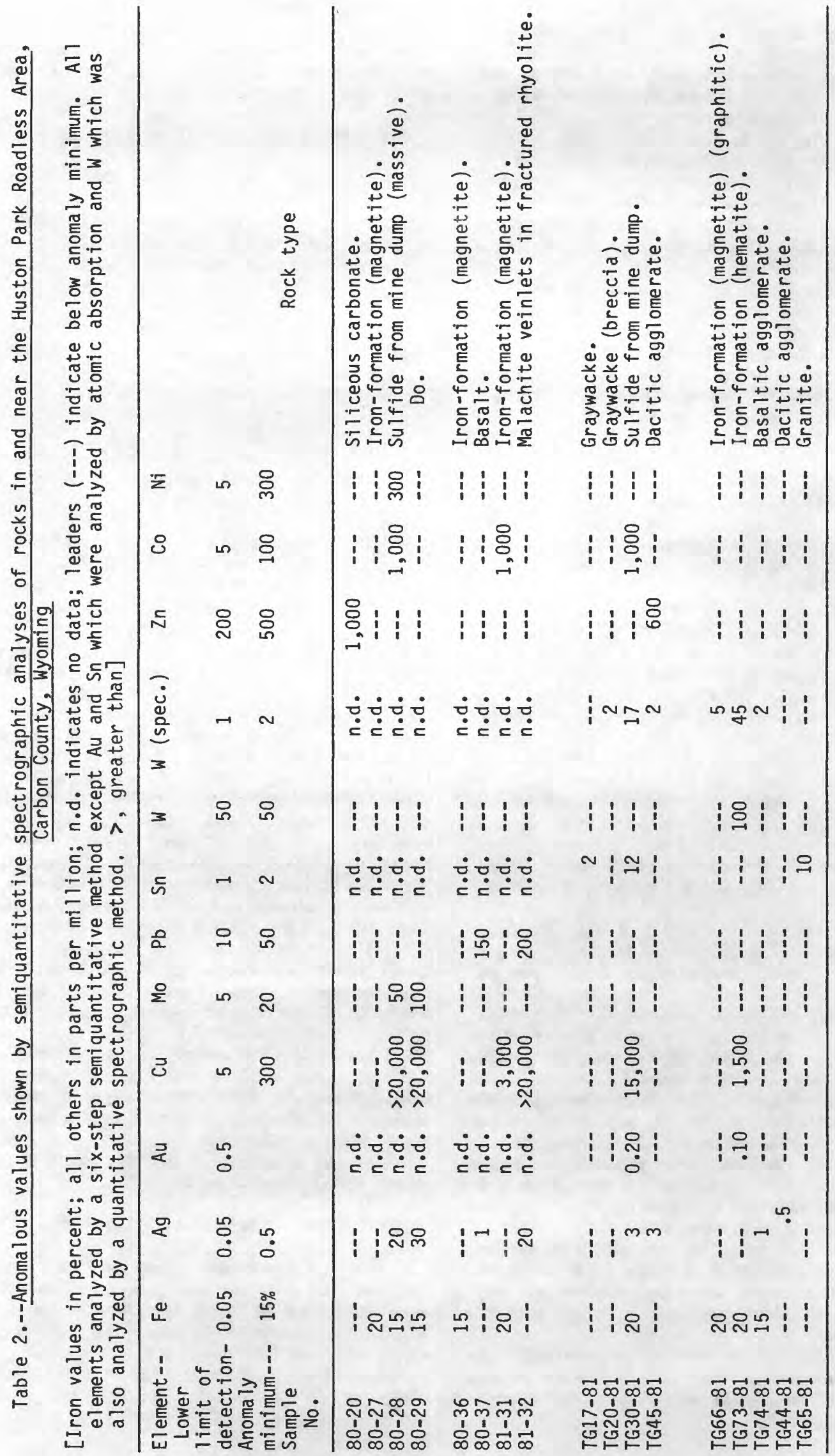


one of these (Itmay area; fig. 1). Exploration drilling will be required to determine if either or both of these prospects is indeed a verifiable stratiform occurrence. The parts of the roadless area that are underlain by volcanic rocks are in secs. 21 and 28 in the northwestern part of the area and sec. 36 in the southeastern part of the area. There are no surface indications of mineralized rock nor were any geochemical anomalies noted in the stream sediments in these areas. Inasmuch as these areas contain volcanic successions that constitute geologic terrane favorable for stratiform deposits, the potential for these parts of the roadless area is moderate for copper resources (fig. 2).

The Huston Park Roadless Area is underlain mostly by granite which invades the volcanic succession and older intrusive rocks. There is geochemical evidence (Divis, 1976, p. 81-82) that the granite was derived by melting of older gneiss. It has been suggested that granites located at or near sutures where island arcs collided with continents and derived partly or wholly by melting of preexisting crust are likely to be hosts of tin and tungsten deposits (Beckinsale, 1979).

Of 11 samples of granite analyzed for tin, only 1 sample (TG65 81, table 2) contained tin (10 ppm). These results are not encouraging, but other samples from the same granite east of the roadless area contain as much as $20 \mathrm{ppm}$ tin. The mean value of 10 samples analyzed from east of the area was $5.5 \mathrm{ppm}$ slightly above the suggested average value of about 3.5 ppm for silicic rocks (Bergerhoff and others, 1978). In addition, both tin and tungsten are present in mineral occurrences within and outside the Huston Park Roadless Area (table 2). Other data also suggest that the concept of tin- and or tungsten-bearing granites should be considered further for the southern Sierra Madre. Some mineral deposits of the southern Sierra Madre are classed as skarns and the mineralization may be related to nearby granitic intrusions. One of these skarn occurrences has as much as $70 \mathrm{ppm}$ tin and both tin and and tungsten are present in vein-type deposits that may have elements derived from the granite. On the basis of negative analytical results in 10 of 11 samples there is no convincing evidence of a potential for tin and tungsten resources in areas underlain by granite in the Houston Park Roadless Area.

\section{REFERENCES CITED}

Beckinsale, R. D., 1979, Granite magmatism in the tin belt of Southeast Asia, in Atherton, M. P., and Tarney, J., eds., Origin of granite batholiths, geochemical evidence: Kent, United Kingdom, Shiva Publishing Ltd., p. 34-44.
Bergerhoff, G., Hamaguchi, H., Kuroda, R., and Wedepohl, K. H., 1978, Tin, in Wedepohl, K. H., ed., Handbook of geochemistry: Berlin, SpringerVerlag, p. 50-A-1 to 50-0-1.

Divis, A. F., 1976, Geology and geochemistry of Sierra Madre Range, Wyoming: Colorado School of Mines Quarterly, v. 71, no. 3, 127 p.

Franklin, J. M., Lydon, J. W., and Sangster, D. F., 1981, Volcanic-associated massive sulfide deposits, in Skinner, B. J., ed., Economic Geology, Seventy-fifth anniversary volume 1905-1980: Lancaster, Pa., Economic Geology Publishing Company, p. 485-627.

Hills, F. A., and Houston, R. S., 1979, Early Proterozoic tectonics of the central Rocky Mountains, North America: Contributions to Geology, v. 17, p. 89-109.

Houston, R. S., and others, 1968, A regional study of rocks of Precambrian age in that part of the Medicine Bow Mountains lying in southeastern Wyoming, with a chapter on The relationship between Precambrian and Laramide structure: Wyoming Geological Survey Memoir 1, $167 \mathrm{p}$.

Houston, R. S., Karlstrom, K. E., Hills, F. A., and Smithson, S. B., 1979, The Cheyenne Belt-A major Precambrian crustal boundary in the Western United States: Geological Society of America Abstracts with Programs, v. 11, no. 7, p. 446.

Lackey, L. L., 1965, Petrography of metavolcanic and igneous rocks of Precambrian age in the Huston Park area, Sierra Madre, Wyoming: Laramie, University of Wyoming M.S. thesis, 78 p.

Mueller, R. E., 1982, Descriptive geology and petrography, $\mathrm{Pt}$. 1 of The Cheyenne Belt, southeastern Wyoming: Laramie, University of Wyoming M.S. thesis, $98 \mathrm{p}$.

Premo, W. R., and Van Schmus, W. R., 1982, U-Pb zircon geochronology of the Sierra Madre Range, Wyoming: Geological Society of America Abstracts with Programs, v. 14, no. 6, p. 346.

Sangster, D. F., 1972, Precambrian volcanogenic massive sulfide deposits in Canada-A review: Geological Survey of Canada Paper 72-22, 44 p.

Snyder, G. L., 1980, Geologic map of the northernmost Park Range and southernmost Sierra Madre, Jackson and Routt Counties, Colorado: U.S. Geological Survey Miscellaneous Investigations Series Map I-1113, scale 1:48,000.

Spencer, A. C., 1904, Copper deposits of the Encampment district: U.S. Geological Survey Professional Paper 25, 107 p.

Swift, P. N., 1982, Precambrian metavolcanic rocks and associated volcanogenic mineral deposits of the southwestern Sierra Madre, Wyoming: Laramie, University of Wyoming M.S. thesis, 61 p.

Wedepohl, K. H., 1969-1978, Handbook of geochemistry: Berlin, Springer-Verlag, v. 1-5. 
